\title{
TRANSPORT
}

DOI https://doi.org/10.30525/978-9934-588-79-2-2.35

\section{ПОКРАЩЕННЯ ТЯГОВО-ЕНЕРГЕТИЧНИХ ХАРАКТЕРИСТИК МАНЕВРОВИХ ЛОКОМОТИВІВ}

\author{
Сріцян Б. X. \\ кандидат технічних наук, \\ дочент кафедри електричного транспорту та тепловозобудування \\ Національного технічного університету \\ «Харківський політехнічний інститут» \\ Рябов С. С. \\ кандидат технічних наук, стариий науковий співробітник, \\ доиент кафедри електричного транспорту та тепловозобудування \\ Наиіонального технічного університету \\ "Харківський політехнічний інститут» \\ Якунін Д. I. \\ кандидат технічних наук, \\ доиент кафедри електричного транспорту та тепловозобудування \\ Національного технічного університету \\ «Харківський політехнічний інститут» \\ м. Харків, Украӥна
}

Аналіз стану парку маневрових тепловозів залізниць України показує, що майже весь парк експлуатується за межами встановленого терміну служби, при цьому значна частина парку має незадовільний технічний стан [1, с. 30]. Внаслідок технічної та моральної застарілості цих тепловозів, їх експлуатація відбувається зі збільшеними витратами у порівнянні із тепловозами, виконаними із застосування сучасного обладнання. Невідповідність технічних характеристик тепловозів характеру та об'ємам маневрової роботи також збільшує експлуатаційні витрати. Тому оновлення парку маневрових тепловозів є однією з першочергових задач для забезпечення стабільних перевезень залізницями України.

Аналіз сучасних тенденцій при створенні (модернізації) маневрових локомотивів дозволяе виділити такі ключові напрями покращення тягово-енергетичних характеристик [2,3]: 
- підвищення тягово-зчіпних властивостей локомотива;

- підвищення енергоефективності локомотива.

Підвищення тягово-зчіпних властивостей локомотива забезпечується застосуванням конструктивних рішень, спрямованих на покращення використання зчіпної маси локомотиву: встановлення довантажувачів візків (тепловози ТЕМ7, ТЕМ103), застосування низько розташованого шквореня (тепловоз ТЕМ103) або похилих тяг (тепловоз ТЕМ21), застосування групового привіду колісних пар (модернізований тепловоз BR203H). Також підвищення тягово-зчіпних властивостей забезпечується застосуванням алгоритмів керування «на межі зчеплення» при індивідуальному живленні тягових електродвигунів.

Підвищення енергоефективності локомотива пов'язане із застуванням у силовий енергетичний установці сучасного обладнання, енергоефективного тягового електроприводу та допоміжних систем, впровадженням енергозаощадливих алгоритмів керування [4]. Зважаючи на специфічні режими роботи маневрового тепловоза (дизельний двигун $50 \ldots 80 \%$ часу працює на холостому ході), доцільною $є$ будова силової енергетичної установки $з$ двох (чи більше) дизельних двигунів, а також застосування накопичувачів енергії. Наприклад, модернізований тепловоз ТЕМ2-УГКМ має допоміжну дизель-генераторну установку, що дозволяє зупиняти головний дизель при очікуванні поїзної роботи [5]. Це забезпечує не тільки скорочення витрат на паливо, а й збільшує термін роботи головного дизеля. Ще більш широкі можливості оптимізувати роботу силової енергетичної установки забезпечує застосування накопичувача енергії, при наявності якого, зокрема, можлива рекуперація енергії. Подібною гібридною силовою установкою обладнані, наприклад, тепловози Н3 виробництва Alstom [6].

Застосування тягового електроприводу на основі електричних машин змінного струму дозволяе як збільшити тягове зусилля, так i забезпечує високі енергетичні показники локомотиву. При цьому шляхом оптимізації мотор-редукторного блоку можливо забезпечити роботу тягового електропривода 3 високими показниками ефективності у режимах роботи тепловоза, які зустрічаються найчастіше.

Суттєве підвищення енергоефективності тягового приводу досягається як за рахунок забезпечення оптимальних режимів роботи компонентів силової енергетичної установки, так і шляхом розподілу навантаження між тяговими електродвигунами [7]. Додатково підвищенню енергоефективності сприяє керування допоміжними системами тепловозу. 


\section{Література:}

1. Артеменко О.В. Удосконалення методів оцінки впливу технічних засобів для енергозбереження на прогрів маневрових тепловозів: дис. ... канд. техн. наук : 05.22.07. Сєверодонецьк, 2019. 186 с.

2. Буряковський С., Маслій А., Панченко В., Помазан Д., Деніс I. Дослідження режимів роботи тепловоза чме3 на імітаційній моделі. Електротехніка і Електромеханіка. 2018. № 2. С. 59-62.

3. Yatsko S., Sidorenko A., Vashchenko Ya., Lyubarskyi B., Yeritsyan B. Method to Improve the Efficiency of the Traction Rolling Stock with Onboard Energy Storage. International journal of renewable energy research. 2019. Vol. 9, No. 2. Pp. 848-858.

4. Бабель М. Теоретические основы и методология выбора объемов и технологий модернизации тепловозов по критерию стоимости жизненного цикла. дис. ... докт. техн. наук : 05.22.07. Москва, 2014. $266 \mathrm{c}$.

5. Модернизированный тепловоз ТЭМ2-УГМК. URL: http://www.shaaz.ru/ru/activity/modernization_of_locomotives/tem2ugmk/ (дата звернення: 20.09.2020)

6. Prima H3 \& Prima H4: Shunting with an eco-friendly attitude. URL: https://www.alstom.com/our-solutions/rolling-stock/prima-h3-primah4-shunting-eco-friendly-attitude (дата звернення: 20.09.2020)

7. Зарифьян А., Гребенников Н., Тахаладзе Т. Концепция повышения энергетической эффективности тепловозной тяги. Интернетжурнал «НАУКОВЕДЕНИЕ». 2017. Т. 9, № 6. С. 1-16. URL: https://naukovedenie.ru/PDF/122TVN617.pdf (дата звернення: 20.09.2020). 